\title{
An Analysis of National Courts Involvement in International Commercial Arbitration; Can International Commercial Arbitration Be Effective without National Courts?
}

\author{
Chinwe A. Mordi \\ Walden University, Minneapolis, MN, USA \\ Email: chinwemordi@yahoo.co.uk \\ Received 18 January 2016; accepted 29 March 2016; published 1 April 2016 \\ Copyright (C) 2016 by author and Scientific Research Publishing Inc. \\ This work is licensed under the Creative Commons Attribution International License (CC BY). \\ http://creativecommons.org/licenses/by/4.0/ \\ c) (7) Open Access
}

\begin{abstract}
Globalisation has prompted the countries of the world to seek effective and efficient methods of dispute resolution which has led to the importance and widespread acceptance of arbitration as a preferred means of dispute resolution without the involvement of the National courts, however, this paper will show that the national courts are involved in the process of arbitration from commencement to recognition and enforcement of the arbitral awards. The purpose of this paper is to propose an appellate arbitral tribunal which will guarantee the independence of the arbitral process from the supervision and strict control of the national courts which is traditionally mandated to administer justice. This research paper aims to examine how national courts have interfered with the process of arbitration and whether arbitration can be effective on its own through an appellate arbitral tribunal. The effect of this study which proposes an appellate arbitral tribunal will, if implemented, will reinforce the confidence of states in the fast effective and final process of dispute resolution through arbitration.
\end{abstract}

\section{Keywords}

Arbitration, Courts, Nigeria

\section{Arbitration in Nigeria}

Nigeria is home to many multi-national companies engaged in oil and gas business or allied services. This presents a constant need to enhance commercial activity in Nigeria and encourage resolution of disputes through arbitration. This need has seen Nigeria ratify and domesticate international conventions such as the New York 
Convention and the UNCITRAL Model Law. These domesticated conventions are pursuant to Nigeria's constitution (Nigeria, 1999), part of the national laws.

Nigeria's earliest attempt at consolidating arbitration was in 1914 when the first statute; the Arbitration Ordinance of 1914 (Nigeria, 199-91914) was enacted, this Ordinance was predicated on the English Arbitration Act, 1889 (Akinbote, 2009). Later that year, the ordinance was replaced by an act and became Arbitration ordinance Act, 1914. Presently, the extant law on arbitration in Nigeria is the arbitration and Conciliation Act 2004 (Nigeria, 2004). This Act was done to:

"Provide a unified legal framework for the fair and efficient settlement of commercial disputes by arbitration and conciliation; and to make applicable the convention on the Recognition and enforcement of arbitral awards (New York Convention) to any award made in Nigeria or in any contracting State arising out of international commercial arbitration”.

\section{Topical Issues of Arbitration}

The problems facing Nigerian domestic arbitration are those that arise out of the interference of the national courts in the arbitration process. The relationship that exists between the national courts and the arbitration tribunal has been termed as "forced cohabitation" (Tweeddale \& Tweeddale, 2005) and a true partnership in that, while one of the fundamentals of arbitration is the resolution of disputes without the courts, arbitration cannot stand on its own two feet. Firstly, it was given birth to by the laws of the national law, secondly, it needs the underlying support of the courts which alone has the power to rescue it when one party seeks to sabotage it and lastly, without the courts to enforce its awards, the awards themselves will only be worth the paper it is written on. However, on the other hand, with increasing international trade and commerce, the national courts need to open their doors to arbitration being a preferred, faster and more effective way of dispute resolution.

This position was brilliantly put by a former English judge who stated that:

"There is plainly a tension here. On the one hand the concept of arbitration as a consensual process reinforced by the ideas of traditionalism leans against the involvement of the mechanisms of state through the medium of a municipal court. On the other side, there is the plain fact, palatable or not, that it is only a court possessing coercive powers which could rescue the arbitration if it is in danger of foundering" (Lord Mustill in Coppee Levalin NV v Ken Ben Fertilizers and Chemicals, 1994).

There are several instances where the court will interfere. Some of them are discussed below. The aim is to highlight the attitude of the courts in its interference with arbitration.

\section{The Arbitration Agreement}

The kernel of international commercial arbitration and indeed the authority of arbitral tribunal rest on the validity of an arbitration agreement between the parties (Abe, 2011). This means that Arbitration is based on a valid agreement to arbitrate. The New York Convention requires that arbitration agreement be in writing and signed by the parties. This calls for two things from the courts. First, the court must determine whether an arbitration agreement is valid and then whether to enforce it. In determining the validity of an arbitration agreement, most courts have developed a progressive approach by looking at the substance, rather than form, thereby enforcing parties' contractual intentions.

Section 1 of the Nigerian Arbitration and Conciliation Act 1998 hereinafter referred to as ACA provides that every arbitration agreement must be in writing for it to be construed as a valid agreement to arbitrate. This provision by implication states that every arbitration agreement must be in writing to be valid. In the case of Alfred Topper Inc. (New York) v. Edokpolor (1965), the plaintiff, a New York company brought an action for the enforcement of an award given in a foreign arbitration, which was governed by the law of New York; a state that had no reciprocal arrangement with Nigeria. The supreme court of Nigeria held that the lower court ought not to have struck out the suit for lack of reciprocity since the plaintiff could sue upon the foreign judgement under common law. However to do this, the plaintiff must prove the existence of a valid arbitration, the proper conduct of the arbitration in accordance with the agreement, and the validity of the award. The lack of a valid arbitration agreement, that is, an agreement in writing could make the award invalid and therefore unenforceable.

Also, the UK Arbitration Act (1996) in section 5 provides that the arbitration agreement must be in writing to 
be valid. In the case of Dallah v Pakistan (Dallah Real Estate \& Touris Holding Co v Pakistan, 2010), as part of the judgement, Mance LJ noted that there appeared to be some overlap and inconsistency between section 102 and section 103 of the Act. This was because under section 102, a party seeking recognition and enforcement of the Convention award has to produce first, the award itself and secondly, the arbitration agreement in writing. He pointed out that the latter could be interpreted to mean an arbitration agreement that is proved to give the tribunal jurisdiction over the party against whom it is sought to enforce the award. Yet issues concerning defects in the arbitration agreement are also dealt with specifically in section 103 (2). Although the enforcement of the award was denied for other reason, the importance of a valid arbitration agreement which includes an agreement in writing is stated. This requirement is important because under the New York convention, one of the few conditions of refusing to enforce an award is if it is not valid, and that includes not being in writing. Furthermore, in the case of Yukos Oil Co v Dardana (Yukos Oil Co v Dardana EWCA, 2002). Mance LJ also stated that, the respondents would have to prove the actual existence of a valid arbitration agreement in writing before the award could be recognised or enforced. Under s. 103 (2), recognition or enforcement 'may be refused' if the appellants could prove one of the matters there listed, which include the absence of any valid arbitration agreement. The above two cases were decided under the Arbitration Act (1996).

On the other hand, the French arbitration law has eliminated the formality requirement for international commercial agreements. Art 1507 of the CCP (French Code of Civil Procedure) Decree (France, 2011). provides that an arbitration agreement which is intended to resolve disputes concerning international trade interests is not subject to any formal requirements. The elimination of the writing requirement under the CCP Decree has been argued as being necessary to accommodate the frequent lack of formal written agreement to arbitrate on the part of the investor in investment arbitrations. This position taken by the French arbitration law flies in contrast to the words of Van Den Berg when he said that "obviously, no arbitration is possible without its very basis, the arbitration agreement” (Berg, 1981). That notwithstanding, while the CCP Decree removes the writing requirements for arbitration agreements, it is reasonable to assume that an arbitration agreement can be made orally. Proceedings for an arbitration that has been made orally will sail smoothly if both parties agree to the terms of the agreement. However, a problem is bound to arise if a party denies the unwritten and in some cases assumed terms of the contact.

Of concern to the writer is the resolution of disputes that arise as a result of the misunderstanding created by these various arbitration laws. It is presumed that when a dispute arises, due to the validity of the arbitration agreement because of its form, the parties will have to refer the dispute back to the national courts for resolution. This is an interesting course of events because the foundations of arbitration is dispute resolution without the courts and, one of the reasons why the arbitration law of France is so party autonomy friendly is to encourage the parties to gain more control over their arbitration process but the race towards total party autonomy pushes the parties back into the hands and therefore the supervision of the national courts.

\section{Arbitrability}

Arbitrability relates to the issues in disputes and whether they are capable of settlement by arbitration. For example, a dispute relating to matrimonial proceedings may not be arbitrable in England but may be arbitrable in Libya. (n.d.), also, Maritime claims are arbitrable in London, but the law is not settled yet on this in Nigeria (Abe, 2011). This is also dependent on public policy of states. The New York Convention is applicable to only disputes that are capable of settlement by arbitration. This is seen in the wordings of Art. II of the New York Convention which provides that;

"Each contracting state shall recognize an agreement in writing under which the parties undertake to submit to arbitration all or any differences which have arisen or may arise between them in respect of a defined legal relationship, whether contractual or not, concerning a subject matter capable of settlement by arbitration" (emphasis provided).

The courts role is to decide whether a dispute is arbitrable or not. This means that there is always need to have recourse to the courts on whether agreements are arbitrable or not. In recent times, some courts have expanded the scope of arbitration to cover subjects like securities and antitrust law, which traditionally are regarded as public policy issues. It is obvious that the courts attitude have been influenced by the need to promote international trade as well as attaining some uniformity in international arbitration. 
The US Supreme Court led the way in the Mitsubishi case, followed by the case of Vimar Seguros S.A. v. M/V Sky Reefer (Vimar v Wilde (Vynior's Case) (1609), where the court enforced arbitration, despite objections that, arbitration clauses in contracts of bills of lading, were not enforceable because it was not freely negotiated. The US Supreme Court in particular holds the view that parties must be made to respect arbitral agreements whilst the issue of public policy is left to reviewing courts to consider when it comes to enforcement of awards under the New York Convention. This has been expressed to be a positive judicial move that will strengthen award enforcement, since public policy differs from each state, as such, an award once obtained can be potentially enforced. Also because refusing to enforce an award because it is against public policy is not encouraging for international commercial arbitration seeing that God forbid that a lawyer should know all the law, so if the parties are unfortunate to choose a country where there agreement is not arbitrable it will be unfair for their agreement to not be arbitrated upon because it does not pass the test of arbitrability.

\section{The Concept of Separability}

This concept means the arbitration agreement contained in a contract exist independently and survive the main contract. Many Jurisdictions now recognize the concept of separability or autonomy of the arbitration agreement. It is recognized by the UNCITRAL Model Law (UNCITRAL Model Law, Art 16(1)), in England (Arbitration Act, 1996, s 7), and in Nigeria. (Arbitration and Conciliation Act s. 5). The courts have given recognition to this concept which is the source of arbitral tribunal's authority.

In the English case of Heyman v. Darwins Ltd (1942), the court held that the arbitration clause will survive to decide the mode of settling the dispute, even when the contract fails. In the Gosset case, the French Cour de Cassation held that the concept of separability in law remains unaffected by invalid contracts. In the SNE v. Joc Oil Case (1989), the Bermuda Court of Appeal held that even though the main contract was void, due to SNE's inadequate signature, the arbitration agreement survived and it was proper for the arbitral tribunal to assume jurisdiction., and in the Nigerian case of Nissan (Nig.) Ltd v. Mr. S. Yoganathan and Sun Motors ltd (2010) where the court buttressed the unassailable nature of the arbitration clause. For example, where an arbitral clause has been considered to be extant by virtue of the imposition of a different rule to the clause, another national law may find the contract null and void. Thus, while the arbitral clause stands, the underlying contract is declared invalid. The consequences of this is whether something can be put on nothing and still stand? (Macfoy v. United Africa Company, 1961). Apparently, without a contractual agreement between two parties, a dispute cannot be said to occur.

Undeniably, the doctrine of separability bears its origin from the age long rule of Competence-Competence (Kompetence-Kompetence). This describes the power of the arbitral tribunal to decide on issues of its own jurisdiction. The tribunals are accorded the legal right to determine their own competence. Thus, in deciding the validity or otherwise of an arbitral clause, the courts generally look beyond the validity of the contract as a whole such that where there is a vitiating element nullifying a contract, the same factors shall not affect the arbitral clause contained in it.

Under this concept, we see the very positive effect of the total autonomy advocated by the French arbitration law. Art.1448 of the CCP Decree provides that the effect of the Competence-Competence principle is the exclusive jurisdiction of the tribunal such that the tribunal can decide what can and cannot be arbitrated upon. This is progress in the right direction toward the independence of the arbitration process from the national courts. Flowing from the discussion of Arbitrability above, matters do not have to be referred to the national courts for determination on whether the issues contained therein are arbitrable or not. This provision in the new French arbitration law is not without conditions. Art 1448 provides that a court can only deal with a dispute covered by an arbitration agreement if the arbitral tribunal has not yet been seized of the dispute. It is assumed by the writer that this provision is necessary to prevent a lacuna in the dispute resolution process. However, it is commended as a positive step towards the independence of arbitration, and it is hoped that more countries will lean towards this direction.

\subsection{Recognition and Enforcement of Awards}

A major characteristic of arbitral awards is that they are binding on the parties. However, in the practice of arbitration, the arbitral tribunal has nothing to do with the recognition and enforcement of an arbitral award. This is because once the award has been given, the arbitrators are deemed to be functus officio; that is, the arbitrators 
ceases to have jurisdiction in the matter of dispute and also, the arbitral tribunal does not have the authority to compel parties to comply with its decisions neither does it have the power to sanction a defaulting party. Consequently, the recognition and enforcement of arbitral awards are done through the national courts.

This paper so far reveals that in almost every step of the arbitration process, the courts have in one way or the other interfered either to clarify a position or to throw the weight of the law behind the arbitration process. It should be noted however that the ways in which the courts interfere in the arbitration process is not limited to the following instances discussed above there are many other situations where the practice of arbitration will have cause to bow to the jurisdiction of the courts. The instances discussed above are to highlight the fact that the practice of arbitration is the opposite of what it was intended to be. That is, a method of dispute resolution without the court. This was succinctly put by one English judge when he said:

"It can be said that if parties agree to resolve their disputes through the use of a private rather than a public tribunal, then the court system should play no part at all... to do otherwise is unwarrantably to interfere with the parties right to conduct their affairs as they choose" (Lord Saville, 1995).

This situation causes the writer to ask, can arbitration succeed without the interference of the national courts?

This paper proposes an appellate arbitral tribunal as the solution for the quest for independence of the arbitration process from the national courts.

\subsection{The Genesis of the Appellate Mechanism Concept}

International arbitration has over the years become the primary method of dispute resolution between states, corporations and individuals in almost every facet of international trade, investment and commerce. The already established centers of arbitration, report increasing activity yearly and more arbitration centers have been set up to be involved in this new trend. This has caused states to adapt their laws to be arbitration friendly. Conferences and seminars on arbitration take place all over the world to train more people to become arbitrators, and the law and practice of international arbitration has become a course for study in law schools and universities.

In the midst of all this activity, it is easy to forget that the original concept of arbitration is a simple one; where parties who are in dispute agree to submit their dispute to a person whose judgment or expertise they trust. The disputing parties each put forward their respective cases to this person (the arbitrator). The arbitrator then listens to the parties, considers the facts and the arguments put forward to him and makes a decision. That decision is taken as binding and final on the parties. The decision has the binding power because the parties agree that it should be. There is no coercive power of the state. Simply, Arbitration is a speedy and efficient way of obtaining a final and binding decision on dispute without reference to the law (Redfern \& Hunter, 2009).

This simplicity which embodied the initial thought and practice of arbitration now exists only in textbooks on the subject. The reality as seen in the discussions above is that arbitration works efficiently and effectively because it is cohabiting with national laws and it is held together with a complex web of international treaties. A simple international arbitration may require recourse to at least four different laws or international conventions; first you have the law of the seat of arbitration the lex Arbitri, then, the law of the place of enforcement, the New York Convention, and in many cases also, the UNCITRAL Rules.

The discussion above have shown the extent of interference of the national courts in the arbitration process, right from the determination of the validity of the arbitration agreement, to the enforcement of the award. The court doesn't just interfere in the recognition and enforcement of the arbitral award, the court takes over it.

This contrast of what should be and what is, prompts the writer to propose an appellate arbitral tribunal. For many academics, the question is not simply whether one is for or against an appellate mechanism, but how one will deal with the practical problems in making the concept a reality (Gantz, 2005) and whether indeed the proposed appellate arbitral tribunal will overcome the challenges facing the practice of international commercial arbitration.

\subsection{Privacy}

The need for privacy is a fundamental reason why parties arbitrate their disputes. This need is fueled by the fact that most of the disputes brought to arbitration are brought either on behalf of the states or of multinationals and if made public, has the tendency of tarnishing the reputation. This guarantee of privacy is punctured when parties approach the national court for the determination of their matter because court proceedings are public and 
are accessible to the public. The proposed appellate arbitral system is presumed to remedy this situation by remaining within the umbrella of arbitration and outside the national courts; parties can retain their right to privacy as under arbitration.

\subsection{Speed of Service}

The rational for this appellate tribunal is to achieve a fast and efficient arbitration process. One of the reasons why parties use arbitration in the resolution of their disputes is because it is assumed that the process is faster than that of the national courts. In some cases, such as where there are no disagreements on the terms and the validity of the arbitration agreement, this is true of the arbitration process. But in cases where there is a disagreement as to the terms of the arbitration agreement or the validity of the agreement, there needs to be an interim protective measure. The arbitration process cannot boast of speedy service because the parties go to the courts for the determination of any of the issues mentioned above and this subjects the parties to the pace of determining disputes by the courts.

The appellate arbitration tribunal will remedy the cause for delay by being the body which the parties will approach in case of any disagreements. Such as in determination of the terms of the agreement, Arbitrability or in cases where there is need for application of interim measures. In the case of interim measures, academics have expressed concern over giving the arbitrators such powers. Their concern is founded on the fact that sometimes, the assets that needs to be protected is in another country and the mechanisms of law enforcement of that country is needed to effectively put an injunction or carry out other legal measures as the case may be on the asset. In response to that concern, the writer suggests that as countries enter into reciprocity agreements with other countries to enable them enforce such orders or carry out such measures; the arbitral tribunal can be elevated to that status also. It should be noted here that the proposed arbitral tribunal does not mean advocating that the existing systems of law enforcement be abolished but that the appellate arbitral tribunal be recognized and given that status and backing of law to enable it carry out the functions that the courts undertake in respect to arbitration.

\subsection{Certainty}

Another cause for the proposal of an appellate arbitral tribunal is certainty. When parties subject themselves to the laws of a state they choose or the law of the seat of arbitration, those laws sometimes contain provision unknown and in some cases unfavorable to the parties. The appellate arbitral tribunal will provide a situation where by there is a uniform set of laws governing arbitration appeals and parties know what to expect when approaching the tribunal. A concern that might be raised in respect to this point is that, being that it is international commercial arbitration, which appellate tribunal will be parties seek redress in? it is proposed that at the point of agreeing to arbitrate, the parties will decide that in the event of any disagreement, they will approach the appellate arbitral tribunal of country $\mathrm{X}$. this will dispel any bouts of uncertainty as to the law that will be applicable. This will remedy the situation of approaching the national courts of the said country $\mathrm{X}$ and being bound by their law which may contain provisions unknown or unfavorable to the parties.

\subsection{Public Policy}

The issue of public policy cannot be ignored in the proposal of the appellate arbitral tribunal. This is also an issue for the courts in the practice of arbitration because what may be accepted in one country may be against public policy in another. As stated above, the proposed appellate arbitral tribunal is not intended to abolish existing legal structures but to be recognized and elevated to the point where it takes decisions for itself, and as such regarding public policy, the proposed appellate arbitral tribunal will have the authority to make decisions or take a stand on public policy issues as do the national courts.

\subsection{Constitution of the Appellate Arbitral Tribunal}

Redfern and Hunter wrote in the book, that the Model law tries to exclude the involvement of the courts as much as possible by stating that; "in matters governed by this law, no court shall intervene except where so provided" but out of the 36 articles that is contained therein, no less than 10 acknowledge the possible role of the "competent court". This role includes constituting the arbitral tribunal, deciding upon a challenge to an arbitrator, or 
doubts about an arbitrator's impartiality or independence. These concerns are well founded but can be handled by the appellate tribunal by being the body that the parties will refer any of the above issues to.

The point above raises the question of who will constitute the appellate arbitral tribunal. It is suggested that the appellate arbitral tribunal will be constituted by retired judges of the state. This is because these are judges that are used to the system of enforcing justice and they already have an education and experience in resolving disputes. It should be seen as an investment by states to establish an appellate arbitral tribunal and place the arbitrators (former judges) on a fixed income so that their loyalty is to the proper execution of justice rather than to the highest bidder.

\subsection{Cost}

The above point will also address the issue of rising cost that comes with a private system of dispute resolution. This is because if the arbitrators are on a fixed income by the government, the parties would not need to empty their pockets in the pursuit of effective and speedy justice.

\subsection{Regulation of the Appellate Arbitral Tribunal}

Another issue that may arise is what law will govern this proposed arbitral tribunal? As stated before, the proposed arbitral tribunal is not intended to abolish the structures of law that already exists, therefore this tribunal will be established by an international convention which will set out the fundamentals but which will act as a base for the countries to add laws peculiar to them. This is in a way saying that the law of the appellate arbitral tribunal will be the best of both worlds, that is, it will have the flexibility of the UNCITRAL model law and the peculiarity of the states. An advantage of this new body of law is that it is not starting from scratch. This means that in passing the convention, the convention makers can take what has worked from the existing laws of arbitration, and leave out the provisions that are either un-useful or complicated. Another advantage is that the laws of the appellate arbitral tribunal will be contained in one single document as against when parties in determination of their dispute by the national courts are subject to at least four documents which are the New York Convention which the state is a party of, the state's law on international domestic arbitration, the UNCITRAL model law, and in some cases, the state's constitution.

\subsection{Recognition and Enforcement of Arbitration Awards}

Of what use will the appellate arbitral tribunal be for the purpose of recognition and enforcement of awards? The proposed appellate tribunals would not change what exists regarding recognition and enforcement of awards, but will use the already established mechanisms of the state in carrying out this function. It is presumed that it will not be much different from what exists now, only that arbitration would have broken up from the cohabiting relationship it shares with the national courts and would have the authority to make and enforce its own decisions.

It should be noted that the appellate arbitral tribunal is not intended to take over the functions, duties nor hierarchy of the states national courts but it is to coexist independent of each other. It is believed by the writer that both systems of law (that is the national courts and the appellate arbitral tribunal) can coexist successfully. This belief is founded on the success of the establishment of the National industrial courts in Nigeria.

\subsection{Case Study: The National Industrial Courts in Nigeria}

The Nigerian National Industrial court, faced with the ever changing structure of employment interrelationship and the challenges of an expanding global society, needed to establish a Court tasked specially to deal with disputes connected with labour and industrial relations. This action became important because labour and industrial disputes are issues that have serious economic bearing, and they need to be dispensed with quickly. The regular Courts were thought to be already saddled with enough duties, and therefore should be spared the additional duties of handling labour and industrial cases. The procedures at the non-specialized Courts were also felt to be too slow and cumbersome and a nation aiming for rapid industrialization and socio-economic development could scarcely afford to be bogged down by such delays and procedures. With this in mind, nations as Trinidad \& Tobago, America and India have in their wisdom established specialized courts to handle labour and industrial disputes. Nigeria also joined this queue by setting up the National Industrial Court (hereinafter called NIC)-a 
specialized Court-to handle labour and trade dispute matters.

It would be worthy to discuss the identified shortcomings the National industrial courts:

1. Both the 1979 and 1999 Nigerian Constitutions failed to include the courts and this led lawyers to disregard its authority by asking that a number of cases decisions reached at the NIC should be judicially reviewed by the Federal High Court. For example, SGS Inspection Services (Nigeria) Limited v. Petroleum and Natural Gas Senior Staff Association of Nigeria (PENGASSAN) (Nigeria, 2006), is one of such cases.

2. Another issue was that of understanding the extent and scope of the subject-matter jurisdiction of the NIC. Although, Decree No. 47 of 1992 seemed to have identified intra and inter union disputes as the major constituent within the purview of the NIC, the courts have proscribed differently that for intra and inter union disputes to be part of the jurisdiction of the NIC, the disputes must qualify as trade dispute 8. Thus describing the relationship between inter and intra union disputes and trade disputes as proscribed above, meant that the intendment of Decree No. 47 of 1992 had been negated thus meaning that some of the cases meant for the NIC could not be entertained there.

3. The interpretation of Case law also created a lot of problems for the court. For example, Kalango V. Dokubo (2003) seemed to hold that only by sections marked expressly as "jurisdiction" in the enabling statute can a court confer jurisdiction by. This decision has therefore declared sections 1A and 19 of the TDA invalid and holding that inter and intra union disputes must qualify as trade disputes for NIC to have jurisdiction on them, the Court of Appeal based its decision, amongst others, on the fact that inter and intra union disputes were not listed in section 20 of the TDA.

4. Another problem created by Kalango v. Dokubo supra is that it again stated that NIC could not grant declaratory and injunctive reliefs. This decision was reached using the case of Western Steel Works Ltd V. Iron and \& Steel Workers Union of Nigeria (1987) as its basis. The effect is that although, the TDA (repealed) established the court as a superior court, it lacked the essential powers of a superior court as it could no grant declarative or injunctive reliefs.

5. The overall implication of the melee created as to what defines the scope of the jurisdiction of the NIC was that several courts at the same time had concurrent jurisdiction on the subject matters on which NIC was supposed to have exclusive jurisdiction. Therefore, the Federal High Court, the 36 High Courts of the States of the Federation, the Federal Capital Territory High Court and the NIC were held to have concurrent jurisdiction in the resolution of labour and trade disputes (Attorney-General of Oyo State v. Nigeria Labour Congress, Oyo State Chapter \& Ors, 2003). The resultant effect was conflicting decisions, absence of clarity and uniformity in the decisions of the various courts on virtually the same issue.

The problems discussed above arose because the NIC was not listed as a superior and hence did not have the power to act. These issues were corrected when the court was re-established by the NIC Act as a superior Court of record.

One major innovation was that the NIC was given a separate enabling law. Just as in the case of all the other federal superior courts of record, the recommending body was made the National Judicial Council. Thus, what obtains in these courts as regards allowances, discipline, tenure, salaries, pension, status and powers were also applicable to the NIC under the NIC Act (Nigeria, 2006). Lastly, the precedents set by the Kalango case that fettered the power of the NIC to grant injunctive and declarative reliefs were declared bad laws by virtue of sections 16 - 19 of the NICA.

The above case study of the National industrial courts of Nigeria was given to illustrate the possibility of the arbitral tribunal and the existing systems of law operating successfully yet independent of each other.

\section{Conclusion}

Dispute resolution systems are as old as man's existence. The act of dispute resolution generates issues regarding practice, effectiveness and efficiency and these issues will continue to stir up debates on what defines best practice application.

Arbitration as an alternative dispute resolution system was created with the intention of dealing with disputes between parties outside the courts, with the judgement based on a prior written and agreed upon agreement. Although many conventions and laws have tried to establish how agreements should be recognised and the awards enforced, these arbitration laws in some cases due to the complexity and in some cases the number of laws needed, brings the need to refer the case to a national court for clarification of a determination of an issue and 
thus, parties then have to go through the whole length of a tedious court proceeding. This action therefore negates the importance of the arbitration process; "dispute resolution outside the courts".

The proposal of an appellate system is borne out of the need to take arbitration (both international and domestic) out of the courts, and empowering it to stand and function independently on its own. This proposed appellate system does not necessarily require a total overhaul of the current judicial structure; it is possible for it to coexist with the structure already on ground. The system just needs to be backed by law, recognised by the public, and for it has its roles and jurisdiction expressively stated and defined.

This appellate arbitral jurisdiction if established will uphold the founding definition of arbitration and also solve other already identified issues challenging the current practice. This proposed appellate system is not being put forward as an answer to all arbitration ails, but it could serve as a spring board for further developing, maintaining and running a better dispute resolution process.

The long standing debate of which theory in the practice of international arbitration is preferred will be laid to rest. The debate is that proponents of the seat and delocalisation theory each present their respective theory as the best for the practice of international commercial arbitration. Supporters of the delocalisation theory uphold total compliance with the concept of party autonomy and state that states should be able to choose the law governing their arbitration proceedings and practice. This choice is said should be without the interference of the national courts. The proponents of this theory state that the involvement of the national courts in the process of arbitration goes against the intention and practice of arbitration and the concept of party autonomy. The advantage of this school of thought is that it gives due respect to the concept of the fundamentals of arbitration such as party autonomy. A practicing state of this school of is France and their support is seen in the Code of Civil Practice 2011.

On the other hand, there is the school of thought that proposes that the law of the seat of arbitration should be the governing law of the arbitration. This school of thought by implication encourages court intervention in the arbitration process. A practicing state of this school of thought such as the United Kingdom states that the theory is better preferred because it gives a degree of certainty to arbitration proceedings and it promotes justice and fairness of the arbitration process.

These schools of thoughts were briefly discussed to put forward the case for the appellate arbitral tribunal. This is because this proposed tribunal will lay to rest this debate by taking out the function of the courts while still retaining fairness, justice and speed of service as discussed in this paper.

\section{Recommendations}

Whether the world is ready for an appellate arbitral tribunal is the question that needs to be answered. The rational for the appellate arbitral tribunal is novel and would no doubt generate review and or debate amongst academics. It is recommended that instead of taking the extreme view of total party autonomy advocated by the French or the seat theory view of the United Kingdom, academics should consider the birth of an appellate arbitral tribunal. Not as a means to all that ails arbitration but as a system of law that encourages and promotes globalization and international commerce.

\section{References}

Abe, O. (2011). Enforcement of Foreign Award in Nigeria. Hungary: Central European University.

Akinbote, A. (2009). Arbitration in Africa-The State of Arbitration in Nigeria. Transnational Dispute Management.

Alfred Topper Inc. (New York) v. Edokpolor (1965). 1 All NLR, 292.

Arbitration Act (1996). s 7.

Arbitration and Conciliation Act s.5 . (n.d.).

Attorney-General of Oyo State v. Nigeria Labour Congress, Oyo State Chapter \& Ors (2003). 8 NWWLR 1. 33-34.

Berg, A. (1981). The New York Arbitration Convention of 1958: An Overview. Vanderbilt Journal of Trans-national Law, 365, pp.

Dallah Real Estate \& Touris Holding Co v Pakistan (2010). UKSC 46 (SC).

France (2011). French Code of Civil Procedure.

Gantz, D. (2005). An Appellate Mechanism for Review of Arbitral Decisions in Investor-State Disputes; Prospects and Challenges (Vol. 703). Tucson, AZ: University of Arizona, Rogers College of Law. 
Heyman v. Darwins Ltd., AC 356 (1942).

Kalango V. Dokubo, 15 NWLR 32 (2003).

Libya. (n.d.). Code of Civil Procedure. Articles 740 and 772 et seq of Document IV, Libya 2.a.

Lord Mustill in Coppee Levalin NV v Ken Ben Fertilizers and Chemicals, 2 Lloyd's Rep 109 (116 (HL) (1994).

Lord Saville (1995). Arbitration and the Courts. Denning Lecture, 157.

Macfoy v. United Africa Company, 3 All ER 1169 at 1172 (1961).

Nigeria (1999). Federal Republic of Nigeria Constitution, § 12.

Nigeria (199-91914). Federal Republic of Nigeria Ordinance, Orders and Regulations 199-91914.

Nigeria (2004). Laws of the Federal Republic of Nigeria Cap A18.

Nigeria (2006). NIC Act 2006. Sections 11-5 and 16-19.

Nissan (Nig.) Ltd v. Mr. S. Yoganathan and Sun Motors ltd., 4 NWLR (Pt. 1185) 135 (2010).

Redfern, A., \& Hunter, M. (2009). Redfern and Hunter on International Arbitration. Oxford: Oxford University Press.

SNE v. Joc Oil Case (1989). 4 International Arbitration Report (July) B1-86.

Tweeddale, A., \& Tweeddale, K. (2005). Arbitration of Commercial Dispute: International and English Law and Practice. New York: Oxford University Press.

UNCITRAL Model Law, Art 16(1). (n.d.).

Vimar v Wilde (Vynior’s Case), 77 Eng. Rep. 595 (KB) (1609).

Western Steel Works Ltd V. Iron and \& Steel Workers Union of Nigeria, 1 NWLR (Pt. 49) 284 (1987).

Yukos Oil Co v Dardana EWCA, Civ 543 (2002). 